\title{
PROPAGANDA: AHOK TIDAK PANTAS JADI GUBERNUR
}

\author{
Adi Prakosa ${ }^{1}$, Abdul Khodir ${ }^{2}$ \\ ${ }^{1}$ Dosen Universitas Nasional \\ adiprakosa@civitas.unas.ac.id \\ ${ }^{2}$ Abdul Khodir Universitas Nasional
}

\begin{abstract}
ABSTRAK
Pers independen dan berita obyektif adalah aturan. Namun pada berita "Ketua DPW Gerindra DKI: Ahok Enggak Indonesia Banget", dalam berita yang dimuat oleh Republika.co.id pada edisi Rabu, 27 Juli 2016, hal-halyang normative itu dilanggar. Hal inilah yang menjadi alasan untuk mengkaji wacana yang disampaikan oleh Republika on line. Metode penelitiannya menggunakan analisis wacana model Fairlcloud. Teori yang dijadikan acuan adalah Teori Kritikal. Hasil penelitian menunjukkan bahwa berita yang dikaji merepresentasikan Ahok tidak pantas jadi gubernur. Terdapat teknik propaganda yang diterapkan, yaitu nama calling, card staking, dan testimonial.
\end{abstract}

Kata kunci: pers, berita, analisis wacana

\section{ABSTRACT}

Independent press and objective news are the rules. But on the news "Chairman of DPW Gerindra DKI: Ahok Enggak Indonesia Banget", in news published by Republika.co.id on Wednesday, July 27, 2016 edition, normative things that are violated. This is the reason to review the discourse submitted by Republika on line. The research method uses discourse analysis of Fairlcloud model. The theory used as a reference is Critical Theory. The results show that the news reviewed represents Ahok inappropriate to be governor. There are propaganda techniques applied, namely the name calling, card staking, and testimonials.

Key words: press, news, discourse analysis

\section{A. Pendahuluan}

\section{Latar Belakang Masalah}

Berita yang disampaikan melalui media massa mempunyai peranan yang sangat penting bagi pembacanya, maupun masyarakat dimana media massa itu hadir. Dengan mendapatkan informasi yang benar dari media massa, khalayak mampu mengambil keputusan yang tepat untuk dirinya maupun masyarakat dan bangsanya demi kemajuan masyarakat dan bangsa itu sendiri.(Hikmat Kusumaningrat, 2007:41) 
Kode etik jurnalistik memberi panduan bahwa media dituntut untuk menjaga independensi, memberikan berita yang akurat, faktual dan berimbang. Selain itu media juga dituntut untuk tidak beritikad buruk berarti tidak ada niat secara sengaja dan semata-mata untuk menimbulkan kerugian pihak lain. Namun pada praktiknya, masih ada media yang mengabaikannya. Media menjadi bagian dari kepentingan politik. Berita yang disampaikan jauh dari kadar obyektivitas.

Paradigma kritis mempunyai pandangan tersendiri terhadap berita, yang bersumber pada bagaimana berita diproduksi dan bagaimana kedudukan media bersangkutan dalam keseluruhan produksi berita. Paradigma kritis mempertanyakan posisi wartawan dan media dalam keseluruhan struktur sosial dan kekuatan sosial yang ada dalam masyarakat. Pada akhirnya posisi tersebut mempengaruhi berita, bukan cerminan dari realitas yang sesungguhnya. Paradigma kritis memandang sebuah berita tidak hanya sebuah konstruksi realitas, namun didalamnya terdapat sebuah propaganda yang ditujukan bagi kelompok maupun individu tertentu.

Berangkat dari pemahaman tersebut peneliti tertarik untuk mengkaji berita di Republika.co.id yang berjudul "Ketua DPW Gerindra DKI: Ahok Enggak Indonesia Banget", dalam berita yang dimuat oleh Republika.co.id pada edisi Rabu, 27 Juli 2016. Gubernur Petahana Basuki Purnama atau yang lebih akrab di kenal Ahok merupakan seorang figur yang akhir-akhir ini selalu menjadi sorotan publik, media massa yang acap kali memberitakan isu-isu terhangat mengenai Ahok ditambah perkataan yang sering kali menuai kontorversi keluar dari mulut Ahok menjadikan dirinya seringkali menjadi headline di media massa baik itu cetak maupun elektronik. Republika merupakan media yang tidak luput memberitakan mengenai isu-isu terhangat seorang figure Ahok, melalui media online Republika yaitu Republika.co.id

Selain pertimbangan berkenaan isi (content) berita, juga pertimbangan bahwa frekuensi berita republika yang cenderung kritis terhadap Ahok cukup tinggi. Kekritisan Republika terhadap Ahok seringkali disajikan secara sepihak. Hanya menampilkan pihak yang kritis terhadap Ahok, juga menjadi sesuatu yang patut dikaji.

\section{Metode Penelitian}

Pada penelitian ini penulis akan menggunakan metode penelitian analisis wacana kritis Norman Fairclough, karena titik perhatian dari konsep ini adalah melihat bahasa sebagai praktik kekuasaan. Selain itu karena penelitian kali ini berkaitan atau mempunyai objek adalah berita maka metode penelitian analisis wacana kritis dirasa cocok untuk mengantarkan penelitian ini.Analisis framing dalam hal ini hampir serupa dengan analisis wacana kritis, namun peneliti justru menggunakan analisis wacana kritis pada penelitian kali ini, karena pada penelitian kali ini peneliti tidak hanya sekedar mendeskripsikan struktur dari sebuah wacana seperti pada analisis framing. Lebih dari itu peneliti dengan menggunakan analisis wacana kritis akan menggali lebih dalam mengenai alasan mengenai alasan mengapa sebuah wacana memiliki struktur tertentu, yang pada akhirnya akan berujung pada analisis hubungan sosial antara pihak - pihak yang tercakup dalam wacana tersebut.Selain itu jika framing hanya menganalisis berita sedangkan pada AWK 
lebih dari itu.AWK melakukan wawancara untuk mendapatkan data mengenai praktik wacana, studi pustaka untuk mendapatkan data praktik sosial budaya.

Teknik analisis ini bertujuan untuk mengetahui bagaimana pemakai bahasa membawa nilai ideologis tertentu dengan menggunakan analisis yang menyeluruh. Dalam hal anailisis harus difokuskan pada bagaimana bahasa itu terbentuk dan dibentuk dari relasi sosial dan konteks sosial tertentu.

Norman Fairclough (dalam Eriyanto, 2011: 326) dengan analisis wacana kritis mencoba menghubungkan antara analisis teks pada level mikro dengan konteks sosial yang lebih besar, dalam hal ini sociocultural practice. Pada tahap analisis, ketiga tahapan itu dilakukan secara bersama - sama. Analisis teks bertujuan mengungkap makna, dan itu bisa dilakukan di antaranya dengan menganalisis bahasa secara kritis.Discourse practice mengantarai teks dengan konteks sosial budaya (sociocultural practice).Artinya hubungan antara sosiobudayanya dengan teks bersifat tidak langsung dan disambungkan discourse practice. Pada tingkatan discourse practice, perlu melakukan wawancara mendalam dengan awak redaksi dan melakukan penelitan news room, dengan mengamati proses produksi berita. Ketiga dimensi ini dapat digambarkan sebagai berikut.

Tabel: Tiga Dimensi Kerangka Analisis Norman Fairclough

\begin{tabular}{|l|l|}
\hline TINGKATAN & METODE \\
\hline Teks & Critical linguistics \\
\hline Discourse Practice & Wawancara mendalam \\
\hline Sosiocultural Practice & Studi pustaka, dan penelusuran \\
\hline
\end{tabular}

\section{Sumber: Eriyanto 2011: 326}

Pada teknik analisis data, peneliti akan menganalisis sebuah teks pada berita Ketua DPW Gerindra DKI: Ahok Enggak Indonesia Banget serta mengungkapkan makna - makna yang tersirat pada wacana teks berita tersebut.

Tabel: Dimensi Sosial Budaya Norman Fairclough

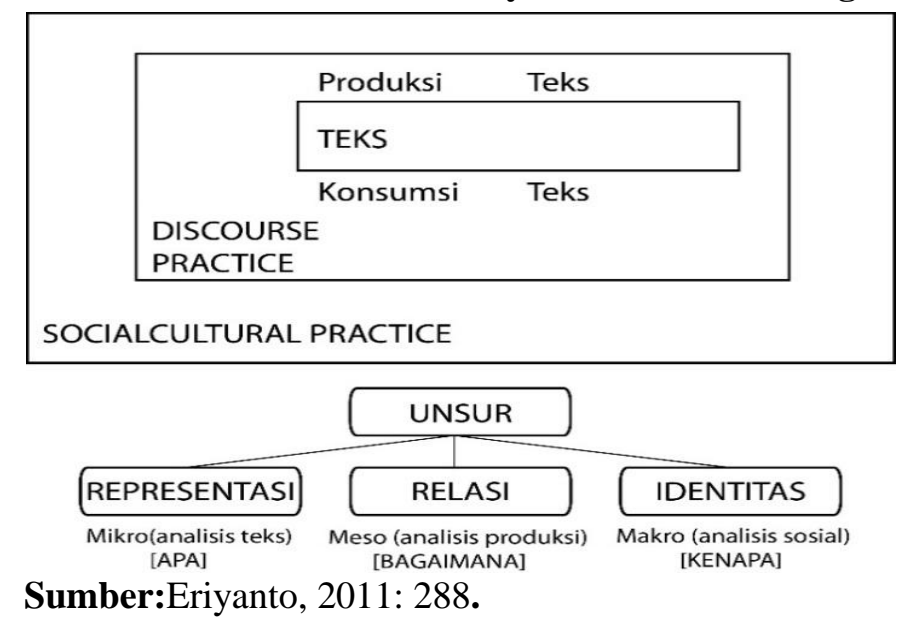


Teks, discourse practice, dan sociocultural practice merupakan tiga unsur utama dalam analisis wacana yang dikemukakan oleh Norman Fairclough. Model analisis Norman Fairclough (dalam Eriyanto, 2011: 288) menjelaskan ketiga dimensi analisisnya dalam menjalankan analisis wacana. Yaitu dimensi teks, discourse practice, dan socialcultural practice.

\section{Teori}

Teori kritis adalah suatu teori yang bersikap kritis terhadap organisasi sosial yang menguntungkan orang tertentu tapi merugikan yang lain. Teori kritis percaya bahwa penelitian adalah tindakan etis dan politis yang selalu menguntungkan kelompok tertentu. Para teoretik kritik seharusnya menguntungkan mereka yang terpinggirkan dalam masyarakat, karena mereka percaya bahwa masyarakat terorganisir secara tidak adil.Karena itu kaum teoritis menganjurkan bahwa penelitian harus memperkuat yang tidak punya kekuasaan (powerless), yang lemah menggantikan kondisi masyarakat yang penuh ketimpangan (inequalities) dan yang tidak adil menjadi lebih adil. (Raco, 2010: 26)

Teori kritis memberikan perhatian yang sangat besar pada alat-alat komunikasi dalam masyarakat.Komunikasi merupakan suatu hasil dari tekanan (tension) antara kreativitas individu dalam memberikan kerangka pada pesan dan kedala-kendala sosial terhadap kreativitas tersebut. Hanya jika individu benar-benar bebas untuk mengespresikan dirinya dengan kejelasan dan penalaran, maka pembebasan akan terjadi, dan kondisi tersebut tidak akan terwujud sampai munculnya suatu tatanan masyarakat yang baru. (Sendjaja, 1994: 393)

\section{B. Pembahasan dan Hasil}

Analisis Teks

Fairclough (dalam Eriyanto, 2011: 289) melihat teks dalam berbagai tingkatan.Sebuah teks bukan hanya menampilkan bagaimana suatu objek digambarkan tetapi juga bagaimana hubungan antarobjek didefinisikan. Ada tiga elemen dasar dalam model Fairclough, yang dapat digambarkan dalam tabel berikut. Setiap teks pada dasarnya, menurut Fairclough, dapat diuraikan dan dianalisis dari ketiga unsur tersebut.

Tabel: Tiga Elemen Dasar dalam Teks Berita "Ketua DPW Gerindra DKI: Ahok Enggak Indonesia Banget"

\begin{tabular}{|l|l|}
\hline \multicolumn{1}{|c|}{ UNSUR } & \multicolumn{1}{|c|}{ YANG INGIN DILIHAT } \\
\hline Representasi & $\begin{array}{l}\text { Ahok tidak pantas menjadi seorang pemimpin atau tidak } \\
\text { pantas mencalonkan diri kembali sebagai pemimpin. }\end{array}$ \\
\hline Relasi & $\begin{array}{l}\text { Adanya pola hubungan atau kedekatan antara ROL } \\
\text { dengan Ketua DPW Gerindra DKI. }\end{array}$ \\
\hline Identitas & $\begin{array}{l}\text { Wartawan mengidentifikasi dirinya bagian dari } \\
\text { kelompok Ketua DPW Gerindra DKI. }\end{array}$ \\
\hline
\end{tabular}

Sumber: Hasil Penelitian 
Dengan menggunakan analisis teks, penulis akan meneliti level teks pada berita "Ketua DPW Gerindra DKI: Ahok Enggak Indonesia Banget" (Rabu 27 Juli 2016) pada situs www.republika.co.id, dan terbagi atas berikut:

\section{Representasi}

Pada tahapan dalam penelitian ini, representasi berbicara mengenai bagaimana peristiwa, orang, kelompok situasi, keadaan, atau apapun ditampilkan dalam teks berita. Pada berita berita "Ketua DPW Gerindra DKI: Ahok Enggak Indonesia Banget" (Rabu 27 Juli 2016) pada situs www.republika.co.id, dalam naskah tersebut memberitakan mengenai pendapat ketua DPW DKI Gerindra yaitu Ketua DPW Gerindra DKI menyebut Basuki Tjahja Purnama (Ahok) sebagai pribadi yang tidak mencerminkan budaya indonesia. Hal tersebut didasarkan pada pernyataan dari Ketua DPW Gerindra DKI, bahwa semenjak Basuki Tjahja Purnama alias Ahok keluar dari fraksi partai Gerindra, Ahok mengalami perubahan sikap menjadi arogan dan tidak beradab.

Jika merujuk pada nilai layak berita Keakuratan sesuatu fakta tidak selalu menjamin arti. Fakta-fakta yang akurat yang dipilih atau disusun secara longgar atau tidak adil sama menyesatkannya dengan kesalahan yang sama sekali palsu. Dengan terlalu banyak atau sedikit memberikan tekanan, dengan menyisipkan fakta-fakta yang tidak relevan dengan menghilangkan fakta-fakta yang seharusnya ada di sana, pembaca mungkin mendapat kesan yang palsu. Dalam hal ini penulis melihat adanya sebuah tekanan terhadap figur Ahok, dalam berita tersebut naskah hanya menjelaskan mengenai pendapat Ketua DPW Gerindra DKI mengenai pribadi Ahok yang cenderung negatif.

Sementara dari pihak atau kubu Ahok sendiri dalam berita tersebut tidak sama sekali diberitakan, atau memberikan statement. Hal tersebut mengisyaratkan bahwa dalam berita tersebut naskah terkesan berat sebelah, dan memberi tekanan terhadap pribadi seorang Ahok.

Dengan pemakaian kata seperti tak beradab, arogan serta Enggak Indonesia banget, perubahan sikap Ahok semenjak keluar dari Gerindra dimaknai sebagai perubahan sikap yang cenderung kearah negatif serta mendiskriminasikan Ahok. Sebaliknya dalam kata Ahok semenjak keluar dari Gerindra berubah sikap menjadi tegas, serta tidak berada. Dalam hal ini penulis mensejajarkan sikap Ahok yang arogan serta tidak beradab, dengan Tegas serta Tak pandang bulu, sering kali kita melihat di media perkataan - perkataan Ahok yang ceplas - ceplos, terutama terhadap bawahannya yang tida disiplin terhadap aturan maupun masyarakat yang tidak tunduk dengan aturan. Hal tersebutlah yang memunculkan anggapan bahwa Ahok cenderung arogan dan tak beradab, namun disamping itu tentu tidak mengkesampingkan fakta bahwa sikap tersebut mencerminkan tindakan yang tegas serta tidak pandang bulu terhadap bawahannya serta masyarakat yang melanggar peraturan.

Jadi hal yang menarik di sini bukan hanya bagaimana pilihan kata yang dipilih dalam menggambarkan realitas tentang Ahok yang berbeda, tetapi juga bagaimana realitas terhadap Ahok yang sama dapat dibahasakan secara berbeda. Dalam berita yang dimuat oleh Republika.co.id perubahan sikap Ahok dapat 
direpresentasikan adalah perubahan sikap yang negatif dan hal tersebut tidak cocok untuk seorang pemimpin seperti Ahok.

Tabel: Perbedaan Realitas yang Digambarkan pada Teks Berita

"Ketua DPW Gerindra DKI: Ahok Enggak Indonesia Banget"

\begin{tabular}{|l|l|}
\hline Tak beradab & Tidak mempunyai mempunyai budi bahasa yang baik \\
\hline Arogan & Mempunyai perasaan yang superioritas \\
\hline Tegas & Pasti, tidak ragu - ragu dan jelas \\
\hline Tak Pandang bulu & Tidak membeda - bedakan \\
\hline
\end{tabular}

\section{Sumber: Hasil Penelitian dari Kamus Besar Bahasa Indonesia}

\section{Relasi}

Jika representasi berhubungan dengan pertanyaan bagaimana seseorang, kelompok, kegiatan, tindakan, keadaan atau sesuatu ditampilkan dalam teks, maka realsi berhubungan dengan bagaimana partisipan dalam media berhubungan dan ditampilkan dalam teks. Fairclough (dalam Eriyanto 2011, 299) berpendapat bahwa ada tiga kategori partisipan utama dalam suatu media; wartawan (reporter atau redaktur), khalayak media, dan partisipan publik (politisi, pengusaha, tokoh masyarakat). Titik perhatian dari analisis hubungan atau relasi, bukam pada representasi mengenai representasi mengenai partisipan publik, melainkan mengungkap pola hubungan antara ketiga aktor tadi disampaikan didalam teks.

Tabel 4. 1 Gambaran Partisipan Publik

\begin{tabular}{|l|l|}
\hline \multicolumn{2}{|c|}{ Teks Berita } \\
\hline Ketua DPW Dartisipan publik) & Ketua DPW DKI Gerindra Muhammad Taufik \\
menyebut Basuki Tjahaja Purnama (Ahok) sebagai \\
sosok yang baik ketika masih menjadi kader partai \\
Gerindra."Enggak begitu, senyum, baik-baik. Baik- \\
baik banget. Sikapnya juga baik," katanya, Selasa \\
(26/7).Taufik mengatakan sikap Ahok mengalami \\
perubahan usai keluar dari Gerindra. Ia menilai \\
Ahok makin tak beradab dengan sikapnya yang \\
arogan."Sejak keluar dari rel-rel keadaban. Sejak \\
ahok tidak beradab. Semua dong, kan saya bilang \\
orang lapor dituding maling, orang datang \\
dibentak-bentak. arogannya \\
dipertontonkan publik. Enggak Indonesia banget," \\
ujarnya.Lebih lanjut, Taufik mengakui Ahok \\
menuduhnya mengkoordinir aksi demonstrasi yang \\
terjadi di Balai Kota. Ia membantah tudingan itu \\
dengan beralasan bahwa setiap rakyat berhak \\
menyatakan pendapat di Balai Kota."Kalau itu kan \\
Ahok sering nuduh orang kan sering, jadi enggak \\
usah kaget lah," ucapnya.
\end{tabular}

Sumber: Hasil Penelitian 
Dalam teks berta diatas penulis melihat bahwa berita lebih menempatkan hubungan dengan Ketua DPW Gerindra DKI, hal tersebut terlihat dengan dominannya pernyataan Ketua DPW Gerindra DKI yang mengomentari kepribadian Ahok. Dalam hal ini penulis menemukan adanya pola hubungan atau kedekatan antara ROL dengan Ketua DPW Gerindra DKI, pada berita tersebut. Hal tersebut tercermin dari bagimana ROL memberikan ruang kepada Ketua DPW Gerindra DKI yang notabenya bersebrangan dalam hal politik, untuk mengutarakan pendapatnya dan mengomentari sikapnya terhadap Ahok. Dan hal tersebut tidak diberikan terhadap Ahok.

\section{Identitas}

Fairclough (dalam Eriyanto, 201: 230) melihat bagaimana aspek identitas wartawan ditampilkan dan dikonstruksi dalam teks pemberitaan. Menurut Fairclough, dari sini kita dapat melihat serta mengidentifikasi posisi atau bagian dari kelompok mana wartawan itu berada. Apakah wartawan tersebut lebih mengidentifikasikan dirinya bagian dari khalayak atau mandiri. Dari wacana pada berita ROL yang berjudul "Ketua DPW Gerindra DKI: Ahok Enggak Indonesia Banget", kita bisa menganailisis apakah wartawan menempatkan diri sebagai bagian dari Ketua DPW Gerindra DKI, Ahok, atau mandiri

\section{Tabel: Identifikasi}

\begin{tabular}{|l|l|}
\hline \multicolumn{2}{|c|}{ Teks Berita } \\
\hline Identifikasi dengan Ketua & $\begin{array}{l}\text { Taufik mengatakan sikap Ahok mengalami } \\
\text { DPW Gerindra DKI }\end{array}$ \\
& Ahok makin tak beradab dengan sikapnya yang \\
arogan. Lebih lanjut, Taufik mengakui Ahok \\
menuduhnya mengkoordinir aksi demonstrasi \\
yang terjadi di Balai Kota. Ia membantah \\
tudingan itu dengan beralasan bahwa setiap \\
rakyat berhak menyatakan pendapat di Balai \\
Kota.
\end{tabular}

\section{Sumber: Hasil Penelitian dan www.Republika.co.id}

Dalam teks berita tersebut, kita dapat identifikasi bahwa wartawan dari ROL merupakan bagian dari kelompok Ketua DPW Gerindra DKI, hal tersebut dapat terlihat bagaimana identitas seorang wartawan ditampilkan dan dikonstruksi dalam teks pemberitaan, dalam hal ini penulis melihat bahwa wartawan lebih fokus terhadap pernyataan yang diutarakan oleh Ketua DPW Gerindra DKI kepada Ahok. Wartawan ROL mengidentifikasikan dirinya sebagai kelompok yang berlawanan dengan Ahok, dengan bagaimana wacana yang ditampilkan dalam teks berita kepada khalayak.

\section{Discourse Practice}

Menurut Bilal Ramadhan selaku redaktur pada berita "Ketua DPW Gerindra DKI: Ahok Enggak Indonesia Banget", sebelum reporter terjun langsung kelapangan akan ada arahan - arahan khusus yang diberikan redaktur terhadap 
reporter, berkenaan dengan penentuan narasumber tertentu, angle berita, dan juga isu sendiri yang ingin diangkat. Seperti berikut hasil wawancara dengan Bilal Ramadhan selaku redaktur berita pada berita "Ketua DPW Gerindra DKI: Ahok Enggak Indonesia Banget”.

"Kita redaktur memberikan isu - isu yang terkini atau angle - angle yang biasanya kita kejar yang lebih update, terutama kita ngomongin online, biasanya malemnya kita kasih agenda terus kemudian arahan - arahan penentuan narasumber, angle berita, serta pertanyaan - pertanyaan yang akan diajukan ke narasumber. Jadi pas hari $\mathrm{H}$ reporter mulai mencari berita kita tinggal nunggu berita yang sudah dikirim oleh reporter ke kantung berita, jadi kita tinggal ngambil berita dari kantung berita. Biasanya kita mengarahkan reporter - reporter dalam sebuah acara untuk mengejar narasumber yang mana, terkait dengan agenda, dan peristiwa - peristiwa yang lagi hits atau yang update. Biasanya dari reporternya sendiri udah tau, harus nyari isu mengenai apa, dan harus mendapatkan narasumbernya siapa, karena kalau reporter biasanya sudah mempunyai sense of news dilapangan, lebih mengetahui kondisi lapangan seperti apa. Selain itu koordinasi penting, semisal narasumber ini tidak ingin diwawancara." - Bilal Ramadhan (Redaktur ROL).

Berkenaan dengan berita ROL yang berjudul "Ketua DPW Gerindra DKI: Ahok Enggak Indonesia Banget" dalam proses praktik wacana, penulis melihat bahwa redaktur mengkontrol secara penuh hal tersebut tidak terlepas dengan adanya arahan - arahan khusus yang diberikan oleh redaktur terhadap reporter berkaitan dengan narasumber serta pertanyaan yang akan diajukan kepada narasumber, dalam hal ini adalah Muhammad Taufik yang menjabat sebagai Ketua DPW Gerindra DKI.

Untuk penentuan judul sendiri Bilal selaku redaktur mengatakan bahwa pengambilan kutipan Ketua DPW Gerindra DKI sebagai judul, guna menghindari kritikan netizen, serta membentengi tersebut dengan hukum. Hal tersebut dikatakan Bilal Ramadhan dalam wawancara sebagai berikut:

"Karena menurut saya, nyari judul dikutipan bisa kuat secara hukum. Kan selama ini sebuah berita itu kalau misalnya sudah sampai ke online, netizen yang baca itu bisa bilang ini beritanya melintir dan tidak sesuai dengan apa yang ditulis. Kalau saya mengambil judul dari kutipan itu kan merupakan kutipan langsung, dan netizen atau khalayak yang membaca tidak bisa membantah, jadi saya selalu membiasakan diri kalau memang ada kutipan kutipan yang enak buat dibaca atau enak diliat, saya selalu jadikan judul. Dibandingkan kita meringkas suatu berita dan kita buat judul sendiri itu bisa membuat penafsiran orang berbeda - beda. Selain itu penentuan kutipan sebagai judul untuk menghindari pertanyaan - pertanyaan dari khalayak atas kevaliditasan berita tersebut, apalagi isu mengenai Ahok itu sensitive, pendukungnya banyak, yang kontra juga banyak." - Bilal Ramadhan (Redaktur ROL). 
Dalam wawancara tersebut Bilal beranggapan bahwa dengan menggunakan kutipan langsung sebagai berita, untuk menghindari pertanyaan - pertanyaan dari khalayak berkenaan dengan validnya sebuah berita, terutama hal yang berbicara mengenai Ahok yang menurut Bilal Ramadhan adalah sesuatu hal yang sensitif. Namun penulis menggaris bawahi bagaimana ROL melihat sebuah pernyataan dengan kenyataan, karena pernyataan dari Ketua DPW Gerindra DKI belum tentu sebuah kenyataan berkenaan dengan perubahan sikap Ahok setelah keluar dari Gerindra. Jika pernyataan tersebut tidak atau berpaling dari kenyataan hal tersebut justru meluntur kan kevaliditasan sebuah berita itu sendiri.

Penentuan Ketua DPW Gerindra DKI yang notabenya "bersebrangan" dengan Ahok, merupakan salah satu bentuk kritik bahkan berbau propaganda yang dilancarkan oleh Ketua DPW Gerindra DKI, yang secara tajam menyoroti sikap Ahok selama menjadi Gubernur dan setelah keluar dari partai Gerindra.

"Berita tersebut latar belakangnya ada pertikaian antara Ahok disini dalam artian sebagai gubernur DKI dengan DPRD DKI, saat itu banyak pertikaian antara Ahok dengan DPRD baik itu dengan Muhammad Taufik atau yang lain seperti Lulung dan beberapa anggota DPRD lainnya. Hubungan Ahok dengan anggota DPRD yang tidak harmonis, salah satunya ramai kasus sumber waras DPRD selalu membicarakan, selain itu masalah - masalah penggusuran itu DPRD selalu berlawanan dengan Ahok pada saat itu yang masih menjabat sebagai gubernur. Dan yang kali ini kalo saya melihat diberita itu Taufik sebagai ketua DPW Gerindra itu dia sebagai oposisi darimana dia menunjukan sikapnya terhadap kebijakan - kebijakan Ahok yang menurutnya mungkin tidak berpihak terhadap rakyat kecil, salah satunya adalah penggusuran - penggusuran seperti kali ciliwung, dan kali jodoh, dan yang terakhir ramai penggusuran di pasar ikan, apalagi yang pasar ikan itu polemiknya juga besar, salah satunya adalah adanya perkampungan muslim didaerah tersebut yaitu masjid luar batang masjid yang cukup tua serta memiliki historis, pertentangannya seperti itu. . Makanya pas reporter bikin berita tentang Muhammad taufik da nada kutipan bagus ya saya jadikan judul. Karena kan memang kalau di berita online penentuan judul sangat penting dalam meraih viewers kalo di online terutama." - Bilal Ramadhan (Redaktur ROL).

Secara historis apa yang dikatakan oleh Redaktur ROL ketika diwawancarai, Ahok dan Ketua DPW Gerindra DKI mempunyai hubungan yang tidak harmonis, hal tersebut terlihat dari beberapa kasus yang pernah terjadi. Pihak DPRD ataupun DPW yang diketuai oleh Muhammad Taufik, selalu bertentangan terhadap kebijakan - kebijakan yang dikeluarkan oleh Ahok selama menjabat sebagai Gubernur DKI Jakarta. Dalam hal ini tentu penulis melihat jika Ketua DPW yang notabenya "bertentangan" dengan Ahok, ketika dimintai pendapat mengenai sosok Ahok, maka pendapat yang keluar dari Ketua DPW justru cenderung menilai Ahok subjektif dan penulis melihat adanya "kesengajaan" dari Redaktur selaku mempunyai kontrol terhadap tersebarnya berita tersebut untuk memilih atau 
menyetujui Ketua DPW Gerindra DKI sebagai narasumber tunggal dalam berita tersebut.

"Dan kenapa taufik, karena sebelumnya itukan kita tahu kalau ahok itu berselisih atau berlawanan arus dengan siapa, salah satunya taufik dan lulung, ahok selalu bersebrangan. Apalagi lulung selalu perang kata - kata dengan lulung, di drprd setau saya hanya dua itu saja. Jadi kalau ada program - program atau kebijakan oleh Ahok, kita akan meminta komentar dari yang mendukung atau yang anti dengan kata lain yang tidak setuju, jadi bagian yang tidak setujunya itu si taufik. Setelah itu kita akan cari dari kubu PDIP yang mendukung Ahok dengan Jokowi dulu sebelumnya. Jadi untuk berita ini kita minta si taufik dan kalau misalkan lulung nanti juga kita pasti bikin karena selain faktor narasumber kita juga mempertimbangkan faktor narasumber tersebut adalah narasumber media darling." - Bilal Ramadhan (Redaktur ROL).

Pada level produksi teks ini juga penulis melihat adanya propaganda pada berita tersebut, baik secara sengaja maupun tidak. Hal tersebut tercermin dari pernyataan Ketua DPW Gerindra DKI yang bernada provokatif, jika pun memang pada berita tersebut memang mengandung unsur propaganda maka dapat diartikan bahwa Ketua DPW Gerindra DKI lah yang menyebar propaganda, karena dia adalah narasumber tunggal pada berita tersebut, hal tersebut diungkapkan oleh Rizky Suryarandika selaku reporter yang menulis berita tersebut seperti berikut hasil wawancara.

"Mengenai apakah berita tersebut mengandung unsur propaganda atau tidak, tentu perlu dikembalikan lagi pada apa saja sebenarnya unsur propaganda?. Saya selaku reporter hanya bertugas menyampaikan fakta, dalam hal ini yaitu pernyataan M.Taufik. Jika berita ini dipandang mengandung unsur propaganda, tentu seharusnya dapat diartikan pula $\mathrm{M}$. Taufik menyebar propaganda karena dialah yang menjadi narasumber berita." - Rizky Suryarandika (Reporter ROL).

Pernyataan yang dilontarkan oleh Ketua DPW Gerindra DKI yang menyebutkan bahwa sikap Ahok yang tidak beradab dan arogan, setelah keluar dari Partai Gerindra tersebut terbilang provokatif, karena hal tersebut akan memicu respon di masyarakat mengingat Ahok yang kurun beberapa waktu belakangan ini menjadi sosok yang amat kontroversi.

Dalam level Discourse practice sendiri aspek individu dari wartawan maupun redaktur juga sangat penting, karena hal tersebut juga berpengaruh terhadap bagaimana teks berita itu diproduksi. Seperti dalam wawancara yang dilakukan terhadap Bilal Ramadhan selaku redaktur berita tersebut, beliau berpendapat bahwa Ahok sendiri merupakan sosok yang tidak pro terhadap rakyat miskin, hal tersebut tercermin dari tidak seriusnya pemerintah DKI memindahkan rakyat miskin yang terkena program penggusuran. Sementara Rizky Suryarandika selaku reporter yang diwawancarai pada tempat berbeda, beranggapan bahwa Ahok merupakan sosok yang kontroversial. Pada satu sisi reporter beranggapan Ahok mempunya sikap 
disiplin tinggi, serta bertanggung jawab terhadap tugas, namun disisi lain reporter beranggapan Ahok juga mempunyai sikap yang kurang santun, serta perdebatan perbedaan suku dan agama yang masih menggunjing di khalayak.

"Terlepas dari semua kabar negatif maupun positif tentang Ahok yang belum bisa dipastikan kebenarannya, saya memandang Ahok sebagai tokoh kontroversial. Faktanya, Ahok bisa dianggap sebagai salah satu Gubernur yang banyak menyumbang bagi pembangunan Jakarta. Kerjanya yang sudah terealisasi yaitu Rusunawa, KJP, pasukan orange, pasukan biru, RPTRA, bersihnya pintu air manggarai, penambahan armada transjakarta, peningkatan fasilitas disabilitas dan Ahok bersedia menerima segala macam laporan warganya langsung dikantornya setiap pagi hari. Sepengetahuan saya, Ahok nyaris selalu datang jam 07.30 di Balai Kota dan pulang lagi sekitar pukul 18.00-19.00 WIB. Saya memandang tak banyak kepala daerah yang rela menghabiskan hampir semua waktunya untuk bekerja di kantor. Di sisi lain, banyak pihak mencela Ahok karena ucapannya dan sikapnya yang dianggap kurang santun. Bahkan ada pula pembenci Ahok karena alasan perbedaan suku dan agama." - Rizky Suryarandika (Reporter ROL).

Dengan itu penulis dapat menyimpulkan bahwa ROL merepresentasikan Ahok tidak pantas untuk menjadi seorang pemimpin, atau maju kembali sebagai pemimpin pada berita yang berjudul "Ketua DPW Gerindra DKI: Ahok Enggak Indonesia Banget".

\section{Sociocultural Practice}

Analisis sociocultural practice didasarkan pada asumsi bahwa kondisi sosial yang berada di luar media yang bersangkutan dapat mempengaruhi bagaimana wacana itu terbentuk dan muncul di dalam media. Dalam hal ini socioculturalpractice tidak langsung berhubungan dengan produksi teks, tetapi socioculturalpractice menentukan bagaimana teks tersebut diproduksi dan dapat dipahami.

Menurut Fairclough (dalam Eriyanto, 2011: 289) cara kerja sociocultural practice dalam menentukan yang akan diproduksi, tidaklah secara langsung melainkan dimediasi atau melalui discourse practice. Dimana dengan melalui discourse practice lah yang nantinya akan muncul analisis sociocultural practice. Namun penulis tegaskan, bahwa sociocultural practice bukanlah merupakan unsur didalam discourse practice, hanya saja untuk mencapai ranah produksi teks sociocultural practice perlu media (discourse practice).

Semisal masyarakat Indonesia mempunyai ideologi Pancasila yang didalamnya terdapat moto atau semboyan Bhinneka Tunggal Ika, namun tidak dipungkiri masih ada beberapa lapisan masyarakat/kelompok masih memiliki sentimen pada agama atau ras tertentu. Kondisi didalam masyarakat yang seperti inilah yang bisa mempengaruhi teks berita diproduksi dan dipahami, apakah dalam berita tersebut dikatakan menyudutkan kaum minoritas, atau sebaliknya, bahkan 
justru tetap dijalur netral itu semua tergantung pada kondisi dilingkungan sosial masyarakat yang berada diluar media.

Berawal dari sentimen agama ataupun raslah yang melatar belakangi proses produksi teks tersebut dalam hal berita di ROL yang berjudul "Ketua DPW Gerindra DKI: Ahok enggak Indonesia banget", memang tidak secara gamblang dalam teks tersebut disebutkan. Namun adanya pendapat Ketua DPW gerindra DKI yang menilai negatif terhadap Ahok, seakan menegaskan bahwa Ketua DPW gerindra DKI ingin mempengaruhi khalayak untuk mulai berpaling dari Ahok dengan menyebut bahwa Ahok pribadi yang tidak beradab dengan sikapnya yang arogan, dengan istilah enggak Indonesia banget merepresentasikan bahwa Ahok tidak pantas untuk menjadi pemimpin di Indonesia khusunya Jakarta.

Berangkat dari pandangan paradigma kritis melihat sebuah media bukan hanya alat dari kelompok dominan, tetapi juga memproduksi ideologi dominan. Media mampu menyebarluaskan gagasan kelompok dominan, lewat medialah, ideologi dominan, apa yang baik dan apa yang buruk dikonstruksikan dalam sebuah berita. Titik penting dalam memahami media menurut paradigm kritis adalah bagaimana media melakukan politik pemaknaan, karena media massa pada dasarnya tidak mereproduksi, melainkan menentukan realitas melalui pemakaian kata - kata yang terpilih.

Atas dasar tersebut maka penulis melihat adanya praktik propaganda pada berita yang dimuat oleh ROL yang berjudul "Ketua DPW Gerindra DKI: Ahok Enggak Indonesia Banget", bagaimana ROL mengkonstruksikan realitas kedalam berita yang cenderung lebih condong terhadap pendapat Ketua DPW Gerindra DKI yang menggunakan konotasi yang negatif terhadap Ahok.

\section{Simpulan}

ROL merupakan media massa yang melakukan propaganda dengan menyudutkan Ahok dengan cara memberikan ruang kepada Ketua DPW Gerindra DKI untuk menyampaikan pendapatnya terkait Ahok.

Hal tersebut di atas tampak dalam pemberian julukan (name calling) yang merepresentasikan bahwa Ahok tidak layak sebagai pemimpin Indonesia, kemudian tebang pilih (Card sataking), fakta dan data menunjukkan konotasi negative dengan mengesampingkan fakta-fakta yang positif tentang Ahok.

Epresentasi di atas diperkuat dengan kesaksian (testimonial), Muhammad Taufik, selaku Ketua DPW Gerinda DKI yang memberikan pendapat yang berkonotasi menjelek-jelekan Ahok dengan tujuan untuk meyakinkan public bahwa Ahok memang tidak pantas menjadi pemimpin. 


\section{Daftar Pustaka}

\section{Buku:}

Budyatna, Muhammad, 2009. JurnalistikTeori\&Praktik.Bandung; PT.RemajaRosdakarya.

C. Merril, John, 1997. Journlaisme Ethics - Philosophical Foundations For News Media.New York; St. Martin's Press.

Eriyanto, 2011.Analisis Isi. Jakarta; Kencana. , 2001. AnalisisWacana, PengantarAnalisis Media. Yogyakarta; LKis Group.

Hamidi, 2007.MetodePenelitiandanTeoriKomunikasi.Malang; UMM Press.

Haryanto, Ignatius, 2014. Jurnlaisme Era Digital.Jakarta; Kompas.

John, Little, W. Stephen, 2009.TeoriKomunikasi. Jakarta; Salemba Humanika.

Kusumaningrat, Hikmat, danKusumaningratPurnama, 2007. JurnalistikTeori \&Praktik.Bandung; PT RemajaRosdakarya.

Moelong, Lexy, 2012.MetodePenelitianKualitatif. Bandung; PT. Remaja Rosdakarya.

Mulyana, Dedi, 2005. KajianWacana: Teori,MetodeAplikasi, danPrinsip PrinsipAnalisisWacana. Yogyakarta; Tiara Wacana.

Patilima, Hamid, 2007. MetodePenelitianKualitatif. Jakarta; Alfabeta.

Prastowo, Andi, 2011. MemahamiMetode - MetodePenelitian. Yogyakarta; Ar Ruzz Media.

Republika.co.id edisi, Rabu, 27 Juli 2016, 01.00WIB 
